\title{
Governance Symposium
}

\section{The Transformative Effect of Public-Private Partnerships: An Inside View of Good Government Under Mayors Voinovich and J ackson}

Vera Vogelsang-Coombs - Cleveland State University William M. Denihan - Alcohol, Drug Addiction and Mental Health Services Board Melanie F. Baur - Cleveland State University

\begin{abstract}
This paper focuses on two mayoral-led public-private partnerships designed to renew good government in Cleveland, Ohio: Mayor George Voinovich's Operations Improvement Task Force (OITF) (1979-1982) and Mayor FrankJ ackson's Operations Efficiency Task Force (OETF) (2006- 2009). The Voinovich OITF public-private partnership enabled Cleveland to "come back" after the city's 1978 default. The Jackson OETF public-private partnership successfully rightsized Cleveland in relationship to its much smaller population needs during challenging economic times without disruptions in service. The authors use three data sources, including interviews with both mayors and their key partnership managers, to gain a complete inside picture of each mayoral-led public-private partnership. The paper concludes with the lessons learned and the governance implications of a mayoral-led public-private partnership in fostering a long-term (transformative) administrative change. This paper shows how both mayoral-led public-private partnerships quietly transformed Cleveland's government to meet the demands of fewer resources, greater complexity, more transparency, and more timely decisions in the delivery of public services to citizens.
\end{abstract}

Keywords: Operations Improvement, Public-Private Partnerships, Urban Change

Editor's Note: We are saddened to announce that Dr. Vera Vogelsang-Coombs died in February 2016. In her memory, we are pleased to publish this article posthumously. At the time of her passing, the article was in the review process. Aside from copy-editing, no revisions have been made to the article since its initial submission.

To avoid fiscal insolvency while modernizing municipal operations to fit shrinking and changing population needs, Mayor George Voinovich and Mayor Frank J ackson of Cleveland, Ohio, have used public-private partnerships to tap into business, nonprofit, and community-based resources to secure a new and positive future for Clevelanders. Specifically, this paper analyzes Mayor Voinovich's Operations Improvement Task Force (OITF) (1979-1982) and Mayor J ackson's Operations Efficiency Task Force (OETF) (2006-2009) from the inside out. Based on this inside-out approach, we show how and why the two mayoral-led public-private partnerships were indispensable to successful management of urban change and the renewal of good government in Cleveland.

Public-private partnerships are elusive to define (Mendel \& Brudney, 2012). After conducting an extensive review of the literature, Ansell and Gash (2008) identified 137 public-partnership cases, but they varied significantly as for their leadership, goals, resources, operations, citizen engagement, and impacts. For the sake of this analysis, we use the definition of publicpartnerships formulated by Mayor Voinovich. In 1979, he was the first big-city mayor to bring together, on a large scale, public, private, and nonprofit stakeholders to work cooperatively to restore the people's confidence in city government after a major debacle-Cleveland's default. For him, a public-private partnership aimed at improving municipal operations meant good government because:

Vogelsang-Coombs, V., Denihan, W. M., \& Baur, M. F. (2016). The transformative effect of public-private partnerships: An inside view of good government under Mayors Voinovich and J ackson. J ournal of Public and Nonprofit Affairs, 2(2), 101-126. doi:10.20899/jpna.2.2.101-126 
Business, nonprofit organizations, and foundations must respond to the call for help from the public sector or suggest on their own initiative their willingness to support the public sector with human capital resources and/ or financial resources...The opportunity for interaction between the public and private sectors allows for progress to be made in improving the city's government and the community as a whole,...In a time of decreasing funding from the federal and state governments, if our cities are to survive and succeed... (Voinovich, 2013).

Our paper has two research objectives. One is to identify the distinctive good government characteristics of Mayor Voinovich's OITF public-partnership that enabled Cleveland to come back after the municipal default caused the city's economic engine to sputter (Steiner, 1999). The second objective is to identify the distinctive good government characteristics of Mayor J ackson's OETF public-private partnership that successfully right-sized Cleveland's government during trying economic times, including the Great Recession of 2008, without disruptions in municipal services to residents.

Our analysis is organized into five sections. The first section describes five good government partnerships that frame our analysis of the Voinovich OITF partnership and the J ackson OETF partnership. The Cleveland setting and the research methodology are discussed in the second section. The third and fourth sections show how Mayors Voinovich and Jackson used the five good government partnership behaviors in implementing the OITF and the OETF partnerships to transform Cleveland successfully. The lessons learned and the governance implications of the mayoral-led public-private partnership are presented in the fifth section.

\section{Five Good Government Partnership Behaviors}

Our analysis of the Voinovich OITF and the Jackson OETF partnerships is grounded in the network scholarship of McGuire and Agranoff. McGuire and Agranoff (2011) define a public management network as one type of collaborative activity involving multiple organizations and multiple perspectives; these organizations join together to solve a major problem that a single entity cannot solve easily or by acting alone. However, public management networks are not panaceas because they have severe limitations, not the least of which is inertia. Therefore, McGuire and Agranoff encourage researchers to study how public management networks can be effectively managed to overcome inertia and deliver results.

Accordingly, our study of the two mayoral-led public-private partnerships in Cleveland examines their inside operations in terms of four network management behaviors identified by McGuire and Agranoff (2014) -activating, mobilizing, framing, and synthesizing. Thus, our research question is as follows: Do the public-private partnerships of Cleveland Mayors Voinovich and J ackson aimed at operations improvement to avoid fiscal insolvency involve the behaviors of activating, mobilizing, framing, and synthesizing? Our research also reveals that the Cleveland mayors adopted a fifth network management behavior that we define as sustaining the public-private partnership results. Each management behavior is defined briefly in turn.

First, activation focuses on the mayor's leadership philosophy, and his partnership vision of operations improvement that requires speedy action to address an urgent municipal fiscal 
situation. Activating behaviors also refer to the mayor's incorporation of key persons and stakeholders who take charge of organizing the governance of the public-private partnership.

Second, mobilization focuses on the mayor's leadership in cultivating the internal and external support for his public-private partnership vision of operations improvement. Thus, mobilization activities generate commitments for securing the information, financial, and human resources needed to operationalize the partnership. An essential aspect of mobilization is the identification of partnership champions and process leaders. Champions are those who sell the public-private partnership idea internally to department heads and city employees and to the external community, including funders, municipal unions, civic groups, elected officials, and county officials; process leaders are the vision keepers who are responsible for the day-to-day management of the public-private partnership.

Third, framing behaviors translate the partnership vision and the commitments for operations improvement into municipal policies and practices. Framing also focuses on building the capacity of partnership external volunteer participants and city employees through training and development. Furthermore, framing includes the establishment of an operations improvement coordinator responsible for monitoring the implementation of the change proposals emerging from the study phase of the partnership process. These framing activities incorporate the practices of professional management into a work culture of delivering excellent city service.

Fourth, synthesizing activities enhance the work conditions that lead to a collaborative environment and productive interactions among the internal and external partnership members. In other words, through synthesis, the mayor and his partnership managers remove the obstacles and create opportunities for the participants to build relationships of trust so that they can focus on the achievement of results. In effect, synthesis behaviors develop a citywide orientation among internal participants that culminate in the successful completion of the partnership's goals and objectives.

Fifth, sustaining behaviors integrate the public-private partnerships methodology of operations improvement into day-to-day municipal governance, resulting in long-term (transformational) urban change. The integration of the partnership's methodology into day-to-day municipal administration makes it less likely for long-term city employees to view operations improvement as the "pet project" of a short-term mayor whose term in office is limited.

\section{Research Setting and Methodology}

The research setting for our analysis of the two mayoral-led public-private partnerships focuses on Cleveland, Ohio, in 1979 and 2006. Our single-city setting is consistent with Mendel and Brudney's (2012) argument that this method controls for contextual differences inside publicprivate partnerships. Given our long view of Cleveland's partnership history, we can differentiate between the short- and long-term (transformational) impacts of the Voinovich OITF partnership and the Jackson OETF partnership, respectively. In this way, our analysis deepens understanding of how the two public-private partnerships successfully helped the city of Cleveland adapt to a changing environment.

Our research uses multiple data sources to provide an inside view of Cleveland's public-private partnerships. The first source is the Voinovich Documents Collection in the Ohio University Library. The Voinovich archives reveal a hidden history of the key actors who worked on Mayor Voinovich's OITF partnership nearly 40 years ago. The second source is a document analysis. 
J ournal of Public and Nonprofit Affairs

We use information gathered from the private collection of Mayor Voinovich and the senior authors who served as volunteers on Mayor J ackson's OETF partnership. Personal interviews are the third data source. Besides interviewing Mayor Voinovich and Mayor Jackson, we gathered information from seven key leaders associated with the Voinovich OITF and J ackson OETF partnerships. ${ }^{1}$

\section{The Five Good Government Partnership Behaviors in the Voinovich OITF}

Table 1 organizes the milestone activities of Mayor Voinovich's OITF partnership by the five good government behaviors listed in the top row. The first column divides the Voinovich OITF partnership into four phases: (1) the formation of the public-private partnership concept; (2) the development of the OITF partnership; (3) the partnership operations; and (4) the partnership's follow-up activities.

\section{Activating Behaviors of Mayor Voinovich (1979)}

Studying government through public-private partnerships inhered in Mayor Voinovich's work ethic. Steiner (1999) described Voinovich as a calm public servant who applied a thoughtful, analytical, and nonpartisan approach to every challenge. Steiner also observed that Voinovich consistently empowered others to help him set a course of action that was best for making a positive difference in the lives of citizens. Voinovich summarized this leadership philosophy of empowerment as "Together We Can Do It" as follows:

I believe government's highest calling is to empower people and galvanize their energy and resources to help solve our problems, meet our challenges, and seize our opportunities. I also believe it's a leader's role to reach deep into every individual, draw out the goodness that's inside, and inspire people to use that goodness to help themselves, their families, and their communities (cited in Riffe, 1999, p. 1).

Moreover, Voinovich combined this leadership philosophy and analytical management approach of operations efficiency with an unwavering commitment to Cleveland.

Voinovich's steadfast conviction to his hometown was evident in his unexpected decision to resign as Ohio's lieutenant governor and run for the Cleveland mayoralty in 1979. At that time, Cleveland was broke - "in fact and spirit" (deWindt, 1981). Due to the high inflation of the late 1970s, Cleveland's expenditures increased dramatically. The city's spending was exacerbated by its geographic size, which was based on 1 million residents. Given that Cleveland's population fell to 573,822 by 1979, budget shortfalls were inevitable. Instead of addressing these budget and structural issues, the city relied on short-run strategies that included the selling of municipal assets, such as its transportation and sewer systems, to receive one-time revenue and by using

1 For information on the Voinovich OITF partnership, we interviewed Ben Bryan, the OITF implementation coordinator, one departmental administrator, and one line manager. For information on the Jackson OETF partnership, we interviewed COO Darnell Brown, the OETF chair, and Michele Whitlow, the manager of the OETF project management office (PMO). Additionally, we interviewed two city council presidents, Martin Sweeney and J ay Westbrook. Of the seven interviewees, two were involved both in the Voinovich OITF and the J ackson OETF partnerships. All hour-long interviews, some in person and others by telephone, took place between J une and September 2014. 
The Transformative Effect of Public-Private Partnerships

federal program funds, such as the LEAA and CBDG, to pay for city operations (Voinovich, 2013).

Moreover, Cleveland residents were suffering due to deplorable living conditions with streets strewn with litter, blighted neighborhoods, racial polarization in the unresponsive police department, and the countless breakdowns in the machinery of government (deWindt, 1981). According to Voinovich (2013), Cleveland was in a dire situation.

The mayor and city council were at war with each other. the administration was at war with the neighborhoods. It was reported that a key administration official punched a nun. The neighborhood people were at war with the police department for a lack of a police response and perceived excessive force. The organization representing black policemen was suing the city for racial discrimination in the department. The city was up in arms over schooling busing and a federal judge that mishandled it. Neighborhoods devastated from the riots of the late 60s [had approximately] 5,000 properties that were in need of immediate demolition. The city-owned electric company became a public football in spite of being on the verge of collapse. Unemployment was about $18 \%$, and the city had a real hunger crisis.

Furthermore, Mayor Dennis Kucinich rejected attempts by the business community to help him address these problems. Instead, he declared war on Cleveland's corporate leaders, publicly denouncing them in national arenas as "fat cats" who wanted to dictate to the "little people" (deWindt, 1981; Vogelsang-Coombs, 2007). The combination of the city's financial instability, its political infighting, and Kucinich's divisive administrative style sparked a special election to recall the mayor. Although Mayor Kucinich narrowly survived the recall, he was unable to secure credit from the Cleveland bankers when $\$ 14$ million in short-term municipal loans came due. In particular, the business community wanted Kucinich to privatize the city's municipal utility (known as Muny Light). Kucinich's refusal to sell Muny Light prompted the Cleveland Trust to demand repayment of its loans, forcing the city to default in 1978.

After the national disgrace of Cleveland's default, E.M. deWindt, the chairman of the Eaton Corporation, organized an intense corporate effort to recruit Lt. Governor Voinovich to run for mayor. To help Voinovich reverse the city's dire direction, de Windt (1981) pledged that he would secure corporate funding to underwrite and provide the human capital necessary for establishing a public-private partnership aimed at improving the operations of Cleveland. Given this pledge, Voinovich shelved his gubernatorial ambition because he realized, he could "do more as mayor.. and because of the dire situation it could be the most significant contribution [he] could make in [his] career in government" (Voinovich 2013). Voinovich's vision for a public-private partnership centered on operations improvement convinced the city's corporate leaders that:

Cleveland would give birth to a rare animal: a task force that would result in action rather than rhetoric. Like most big cities, Cleveland had been studied to near death. In recent years, five separate studies, including a Little Hoover Commission, focused on Cleveland. Each study ended up with a thick, spiral-bound tome and precious little action. We had had enough pretty pictures 
Table 1. OITF Implementation Phases by Good Government Partnership Behaviors of Mayor Voinovich

\begin{tabular}{|c|c|c|c|c|c|}
\hline & Activating 1979 & Mobilizing 1980 & Framing 1980 & Synthesizing 1980-82 & Sustaining 1982-89 \\
\hline $\begin{array}{l}\text { OITF } \\
\text { Partnership } \\
\text { Concept } \\
\text { Formation }\end{array}$ & $\begin{array}{l}\text {-GV PPP premise } \\
\text {-Urgency - Default } \\
\text {-GV recruited by } \\
\text { business community } \\
\text {-Business support for } \\
\text { PPP premise \& OITF } \\
\text {-GV elected mayor }\end{array}$ & $\begin{array}{l}\text {-Overall Champion -GV } \\
\text {-External Champion - } \\
\text { deWindt } \\
\text {-PPP Internal Champion - } \\
\text { Council President Forbes } \\
\text {-Support of Greater } \\
\text { Cleveland Roundtable }\end{array}$ & $\begin{array}{l}\text {-OITF Goal } \\
\text {-Exec. Committee } \\
\text { policy objectives } \\
\text {-GV elimination of } \\
\text { patronage culture }\end{array}$ & $\begin{array}{l}\text {-Legislative support } \\
\text { of City Council }\end{array}$ & $\begin{array}{l}\text {-Ongoing vital } \\
\text { communication } \\
\text { between public \& } \\
\text { private sectors }\end{array}$ \\
\hline OITF & -de Windt, Eaton & -Cleveland and Gund & -Ways and Means set & -OITF Coordinator & -Cleveland Tomorrow \\
\hline Partnership & Corp. Chair and CEO & Foundation Challenge & time frames $\&$ formats & moved into Mayor's & -Community Capital \\
\hline Development & $\begin{array}{l}\text {-OITF Executive } \\
\text { Committee } \\
\text {-Ways and Means } \\
\text { Committee }\end{array}$ & $\begin{array}{l}\text { Grants of } \$ 250,000 \\
\text {-deWindt and Mandel } \\
\text { raised } \$ 544,000 \text { from } 264 \\
\text { sponsors }\end{array}$ & $\begin{array}{l}\text {-Orientation and } \\
\text { training by Warren } \\
\text { King } \\
\text {-GV memo to directors } \\
\text { and commissioners }\end{array}$ & $\begin{array}{l}\text { office } \\
\text {-Working relationship } \\
\text { between the OITF } \\
\text { Coordinator and city } \\
\text { commissioners }\end{array}$ & $\begin{array}{l}\text { Investment Strategy } \\
\text { and Build Up Greater } \\
\text { Cleveland } \\
\text {-Downtown } \\
\text { partnerships }\end{array}$ \\
\hline $\begin{array}{l}\text { OITF } \\
\text { Partnership } \\
\text { Operations }\end{array}$ & $\begin{array}{l}\text {-Centralized and top- } \\
\text { down corporate } \\
\text { governance structure } \\
\text {-Operating } \\
\text { Committee }\end{array}$ & $\begin{array}{l}\text {-PPP Process Leaders: } \\
\text { Warren King and Govt } \\
\text { Services Institute } \\
\text {-Internal Process } \\
\text { Champion: Bryant, OITF } \\
\text { Coordinator } \\
\text {-Financial Audit Task Force } \\
\text {-89 loaned executives for } 12 \\
\text { weeks organized into four } \\
\text { OITF study teams }\end{array}$ & $\begin{array}{l}\text {-Objectives: to reduce } \\
\text { expenses by 5-10\% \& } \\
\text { find productivity } \\
\text { improvements } \\
\text {-Study teams produced } \\
650 \text { recommendations }\end{array}$ & $\begin{array}{l}\text {-Dept. heads required } \\
\text { to write OITF plans } \\
\text { and evaluated on } \\
\text { progress } \\
\text {-Council passed } 60 \\
\text { OITF ordinances } \\
\text {-94\% of OITF } \\
\text { implemented } \\
\text {-Saved \$200 Million } \\
\text {-Workforce down 4\% } \\
\text {-Default ended }\end{array}$ & $\begin{array}{l}\text { - } 1982 \text { charter changes } \\
\text {-14 additional study } \\
\text { teams formed and } \\
\text { funded } \\
\text {-Improved labor and } \\
\text { police-community } \\
\text { relations } \\
\text {-Expanded network } \\
\text { of neighborhood } \\
\text { organ. }\end{array}$ \\
\hline $\begin{array}{l}\text { OITF } \\
\text { Partnership } \\
\text { Follow-up }\end{array}$ & $\begin{array}{l}\text {-Project MOVE } \\
\text { established }\end{array}$ & $\begin{array}{l}\text {-Project MOVE } \\
\text { Implementation } \\
\text { Coordinator managed } \\
8,000 \text { volunteers }\end{array}$ & $\begin{array}{l}\text {-Culture shift to } \\
\text { professional } \\
\text { management }\end{array}$ & $\begin{array}{l}\text {-Original loaned } \\
\text { executives stayed } \\
\text { involved }\end{array}$ & $\begin{array}{l}\text {-End of state fiscal } \\
\text { control in } 1987 \\
\text {-Three All-America } \\
\text { City awards }\end{array}$ \\
\hline
\end{tabular}


The Transformative Effect of Public-Private Partnerships

and multicolored charts. This time there had to be action...and plenty of it (deWindt, 1981).

In November 1979, Voinovich, a Republican, decisively defeated Mayor Kucinich, a Democrat, by receiving $56 \%$ of the votes cast in solidly blue Cleveland.

One day after his election, Voinovich went to work with deWindt to develop the OITF publicprivate partnership. Within three weeks of Voinovich's election, deWindt had the OITF's governing structure in place (see table 2). At the top was a 12-member executive committee that acted as a board of directors, setting the policy objectives, and providing the financial and personnel resources for the OITF. As shown in table 2, the executive secretary of the Cleveland AFL-CIO was incorporated into the OITF's executive committee. Headed by deWindt, the executive committee engaged twenty-one business leaders as members of the ways and means committee. The ways and means committee meticulously recruited and assigned top business specialists to fit the precise technical needs of the OITF study teams. The OITF's implementation rested with a five-member operating committee, headed by Robert Hunter, the CEO of the Weatherhead Corporation. Thus, the OITF public-private partnership was structured as a "business enterprise of global proportions" (deWindt, 1981).

\section{Mobilizing Behaviors of Mayor Voinovich (1980)}

One day after his inauguration Mayor Voinovich sought to determine the true financial condition of the city. A state audit revealed that the city's accounting records were "unauditable" (Voinovich, 2013). Therefore, the Ohio General Assembly placed Cleveland under the fiscal supervision of the state's financial planning commission in J anuary 1980. Consequently, the mayor established the volunteer financial audit task force, which was comprised primarily of accountants from the big-eight firms. The auditors found that the city was \$110 million in debt. In effect, Cleveland's financial position was much bleaker than Voinovich expected. Thus, negotiating a debt repayment plan, restoring the city's positive credit rating, and ending the state's supervision of Cleveland's finances were the mayor's fiscal objectives folded into the scope of the Voinovich OITF public-private partnership.

The external champion of the OITF partnership was deWindt, and, under his leadership, the executive committee raised $\$ 794,000$, including challenge grants of $\$ 150,000$ and $\$ 100,000$ from the Cleveland Foundation and Gund Foundation, respectively. Additionally, deWindt and Morton Mandel, a prominent Cleveland entrepreneur and philanthropist serving on the ways and means committee, generated widespread community support that resulted in $\$ 544,000$ in additional funds for the operation of the Voinovich OITF partnership. Specifically, 264 private firms (88\%) and 36 not-for-profit organizations (12\%) in Greater Cleveland served as sponsors of the OITF partnership. Among the OITF sponsors were eight (8) labor unions (OITF, 1982).

Our interviews revealed that the internal champion of the Voinovich OITF partnership was Council President George Forbes. Shortly after assuming office, Mayor Voinovich met with the council president to persuade him that his OITF partnership agenda was aimed at making Cleveland a better place for everyone everywhere in the city to live. Acconding to Voinovich (2013), the council president was impressed that the Greater Cleveland Roundtable supported the mayor's OITF partnership agenda. By securing the support of the roundtable, the OITF partnership tapped into "our United Nations that dealt with jobs, economic development, and education, labor, and race relations" because "its membership included CEOs, elected officials, religious leaders, union officials, neighborhood activists, and the leaders of the African- 
Table 2. The Voinovich OITF Partnership Structure

\begin{tabular}{|c|c|c|}
\hline Executive Committee & Job Title & Company \\
\hline E.M. De Windt, Chairman & Chairman of the Board & Eaton Corporation \\
\hline Claude M. Blair, Vice President & Chairman of the Board & National City Corporation \\
\hline Carole Hoover, Vice Chairman & President & $\begin{array}{l}\text { Greater Cleveland Growth } \\
\text { Association }\end{array}$ \\
\hline Stanley C. Pace, Vice Chairman & President & TRW Inc. \\
\hline Frederick K. Cox & Vice-Chairman & Ameritrust \\
\hline Dr. Nolen M. Ellison & District Chancellor & $\begin{array}{l}\text { Cuyahoga Community } \\
\text { College }\end{array}$ \\
\hline Fr. Marino Frascati & Priest & $\begin{array}{l}\text { Our lady of Mt. Carmel } \\
\text { Church }\end{array}$ \\
\hline Robert E. Hunter & $\begin{array}{l}\text { Ret. Chairman of the Board } \\
\text { and CEO }\end{array}$ & Weatherhead Company \\
\hline J oseph A. Kocab & Vice President/Asst. Principal & $\begin{array}{l}\text { Czech Catholic Union/ South } \\
\text { High School }\end{array}$ \\
\hline Sebastian Lupica & Executive Secretary & Cleveland AFL-CIO \\
\hline Charles McDonald & Chairman & $\begin{array}{l}\text { Council of Smaller } \\
\text { Enterprises }\end{array}$ \\
\hline Dr. Ruth Miller & News Analyst & WBBG Radio \\
\hline J ohn W. Hushen, coordinator & $\begin{array}{l}\text { Vice President-Corporate } \\
\text { Affairs }\end{array}$ & Eaton Corporation \\
\hline Ways and Means Committee & Job Title & Company \\
\hline E.M. De Windt & Chairman of the Board & Eaton Corporation \\
\hline Claude M. Blair & Chairman of the Board & National City Corporation \\
\hline Harry J. Bolwell & Chairman and CEO & Midland-Ross Corporation \\
\hline J ohn T. Collinson & Chief Executive Officer & Chessie System, Inc. \\
\hline William H. De Lancey & Chairman and CEO & Republic Steel Corporation \\
\hline John J . Dwyer & President & Oglebay Norton Company \\
\hline George J. Grabner & President and CEO & $\begin{array}{l}\text { The Lamson and Sessions } \\
\text { Company }\end{array}$ \\
\hline Robert D. Gries & $\begin{array}{l}\text { Founder and Managing } \\
\text { Director }\end{array}$ & Gries Investment Company \\
\hline Ray J. Groves & Chairman & Ernst and Whinney \\
\hline Roy H. Holdt & Chief Executive Officer & $\begin{array}{l}\text { White Consolidated } \\
\text { Industries, Inc. }\end{array}$ \\
\hline Allen C. Holmes & Managing Partner & $\begin{array}{l}\text { Jones, Day, Reavis, and } \\
\text { Pogue }\end{array}$ \\
\hline William E. MacDonald & President and CEO & $\begin{array}{l}\text { The Ohio Bell Telephone } \\
\text { Company }\end{array}$ \\
\hline Morton L. Mandel & co-founder and Chairman & $\begin{array}{l}\text { Premier Industrial } \\
\text { Corporation }\end{array}$ \\
\hline Charles McDonald & Chairman & $\begin{array}{l}\text { Council of Smaller } \\
\text { Enterprises }\end{array}$ \\
\hline Arthur B. Modell & Owner & Cleveland Browns, Inc. \\
\hline Stanley C. Pace & President & TRW Inc. \\
\hline Patrick S. Parker & President, Chairman and CEO & Parker-Hannifin Corporation \\
\hline Samuel K. Scovil & President and CEO & $\begin{array}{l}\text { The Cleveland-Cliffs Iron } \\
\text { Company }\end{array}$ \\
\hline Herbert E. Strawbridge & President & The Higbee Company \\
\hline Hays T. Watkins & President and Co-CEO & CSX \\
\hline
\end{tabular}




\begin{tabular}{|c|c|c|}
\hline M. Brock Weir & President & Ameritrust \\
\hline Alton W. Whitehouse, Jr. & Chairman and CEO & The Standard Oil Company \\
\hline Operating Committee & J ob Title & Company \\
\hline $\begin{array}{l}\text { Robert . Hunter, Chairman } \\
\text { (1980) }\end{array}$ & $\begin{array}{l}\text { Ret. Chairman of the Board } \\
\text { and CEO }\end{array}$ & Weatherhead Company \\
\hline Stanley S. Czarnecki & Special Agent in Charge & FBI \\
\hline Robert W. Hartwell & President & Cliffs Electric Service Co. \\
\hline $\begin{array}{l}\text { J ames J . McGowan, Chairman } \\
\text { (1981-1982) }\end{array}$ & General Manager & $\begin{array}{l}\text { Ohio Bell Telephone } \\
\text { Company }\end{array}$ \\
\hline Gustav E. Schrader & Vice President & TRW, Inc. \\
\hline
\end{tabular}

Source: OITF (1982)

American, Hispanic, and ethnic communities" (Voinovich, 2013). It is important to note that the mayor excluded tax policy and city council operations from the OITF partnership's scope. In this way, Mayor Voinovich respected the council's prerogatives and gained the support of the council president. Without the council president's behind-the-scene political leadership the work of the Voinovich OITF partnership would have failed.

Two consulting organizations, the Government Research Institute (GRI) of Cleveland and Warren King and Associates (WKA), served as the process leaders of the OITF partnership. ${ }^{2}$ GRI managed the finances of the OITF partnership and provided logistical support to the operating committee. WKA provided the templates for the time frames and the scope of the loaned executive work, the formats of the OITF change recommendations, and the preparation of the final report. The internal process leader was the OITF Implementation Coordinator Ben Bryan who was a contract employee, and his salary was funded by the OITF partnership. Bryan reported directly to Hunter as the operating committee chairman. When Hunter retired in 1982, Bryan was hired as a full-time city employee in the mayor's office, and he reported to Tom Wagner, the city's law director.

The ways and means committee successfully recruited 89 loaned executives for 12 weeks of OITF duty. These volunteers included "lawyers, accountants, administrators; CEOs, and CFOs; engineers experts in computers and human relations and every management discipline" (deWindt, 1981). Four study teams of business volunteers were formed to study the 63 agencies within the city, and the chair of each team was a member of the operating committee. ${ }^{3}$ In effect, every city department and administrative process was within the OITF partnership's purview. Before the loaned executives were embedded in the study teams, WKA trained them about the differences between the public and private sectors, reminded them their purpose was to share best practices respectfully with city employees, and praised them for their willingness to help their hometown.

\footnotetext{
2 Voinovich (2013) modeled the Cleveland Operations Improvement Task Force (OITF) on the successful public-private partnership that Governor Ronald Reagan implemented in California with the assistance of Warren King and Associates.

${ }^{3}$ Led by the vice president of TRW, one team focused on the departments of public properties, port control and public service. Another team, led by an experienced FBI executive, headed the protective services team, focusing on police, fire, and emergency management services. Chaired by a former executive vice president of Detroit Edison, the third team studied public utilities, health, and community development. Led by an Ohio Bell vice president, the fourth team focused on general government, and its scope included the mayor's office as well as the departments of personnel and finance (OITF, 1982).
} 


\section{Framing Behaviors of Mayor Voinovich (1980)}

The stated goal of the Voinovich OITF partnership was: "To help improve the quality of life for the people of Cleveland by making local government more responsive to citizen needs." To frame the work of the OITF study teams, the executive committee set the following objectives: (1) identify immediate opportunities for increasing efficiency and improving cost effectiveness that could be realized by executive or administrative order; (2) suggest managerial, operating and organizational improvements for immediate and long-term consideration by the mayor and city council; and, (3) pinpoint specific areas where further in-depth analysis could be justified by potential short or long-term benefit (OITF, 1982).

Mayor Voinovich's unwavering commitment to the OITF partnership set a positive tone throughout the city and framed his larger focus on the primacy of professional management. However, when Voinovich assumed office, city hall operations were chaotic, and staff morale was low. As a group, the city commissioners (the highest civil service ranking employees) felt broken, and the rank-and-file employees were afraid that "heads would roll" based on what the loaned executives would do.

Within three weeks of taking office, Mayor Voinovich sent a memo to reassure city managers and build their support for the OITF study process. Specifically, he asked all department directors and city commissioners to provide an itemized list of the status of service in their units, using a rating scale of "inadequate," "adequate," and "more than adequate" service. The mayor also encouraged them to share their thoughts about how to organize their departments to function better and more efficiently. Their responses were fed back to the OITF study teams and ultimately became a part of the OITF partnership's change proposals. Voinovich believed this employee-centered process helped him gain the management staff's confidence in the partnership's goal of operations improvement.

To build staff morale, Voinovich established a culture of professional management at city hall. One way he did this was to remove the patronage politics that pervaded city administration. In particular, he eliminated the requirement for city employees to kick back a portion of their salary by buying or selling tickets for mayoral campaign fundraisers. Voinovich made it clear to all city employees that he would base their evaluations on their job performance rather than on the number of campaign tickets they sold or on their personal relationships with the mayor (Voinovich, 2013).

Another way Voinovich professionalized the culture was by his involving city employees in the OITF study process. In framing the OITF, he approached them to find out what they were doing right by soliciting their ideas about what they could do better. The message he sent was: how can we help you do your job better, smarter, and in the most cost-effective way? (Voinovich, 2013). In addition, the OITF implementation coordinator met regularly with every city commissioner, thereby tapping into their expertise and institutional knowledge of the 63 operating units. Without this employee-centered process to frame the OITF partnership, Voinovich believed that improving the city's operations would not have been possible (Voinovich, 2013).

\section{Synthesizing Behavior of Mayor Voinovich (1980- 1982)}

Unlike the strife characterizing Mayor Kucinich's relationship to the city council, Mayor Voinovich restored civility between Cleveland's executive and legislative branches. Moreover, the council president as the internal OITF partnership champion was a true ally of the mayor 
because privately he built the political majority necessary to enact the OITF change proposals. Eventually, the council passed 60 OITF-related ordinances that focused on operations, management, and service delivery.

Within 90 days of its inception, the OITF partnership delivered a comprehensive evaluation of Cleveland's city government. This report had 650 workable recommendations, each of which was vetted and edited by the operating committee. Afterward, Mayor Voinovich required his department directors to develop implementation plans for their units, and he evaluated their performance heavily in terms of their progress. The mayor also met weekly with the operating committee and the OITF implementation coondinator, whose sole responsibility was to track and facilitate the progress made in carrying out the improvement recommendations. Once a month, the mayor devoted time at his cabinet meeting for the department heads to report to their peers their progress in implementing their OITF action plans. Informally, Mayor Voinovich conferred "eagle" and "jackass" awards to those department heads who made an outstanding or a limited effort, respectively, in carrying out their OITF commitments. The leadership and direct engagement of Mayor Voinovich in synthesizing the OITF implementation activities was vital to the partnership's success.

Overall, $94 \%$ of the OITF recommendations were implemented that reduced the city workforce by $4 \%$ and saved $\$ 200$ million collectively (OITF, 1982). Additionally, Mayor Voinovich reorganized 10 departments, instituted an accounting system with internal auditing capabilities, and achieved savings of \$57 million annually. He also set controls on police overtime and adopted a computerized communication system to speed up the response time of safety forces, streamlined purchasing transactions, instituted a city-wide vehicle control and maintenance system, revamped the snow removal process, upgraded data-processing capabilities, and improved personnel procedures (deWindt, 1981; OITF, 1982). By the end of 1981, Cleveland was no longer in default, and the city achieved an investment grade for its credit rating; fiscal control was returned to the city when the state's supervisory commission disbanded in J une 1987.

At its conclusion in March 1982, the leadership of the OITF partnership delivered a second report to Mayor Voinovich. This report directed the mayor's attention to the needed middle- and long-term strategies for the professional management of Cleveland's finances and service delivery. Based on this report, Mayor Voinovich and the OITF executive committee identified 14 major improvement projects, including an enhanced computer-aided dispatch system for the police department; a wage and salary administration study; a building maintenance system; EEO program assistance; a fire location study; and a payroll system. The mayor used $66 \%$ of the funds raised by the OITF public-private partnership (or $\$ 596,000$ ) to cover the cost of implementing these 14 projects.

An important synthesizing feature of the Voinovich OITF partnership was that it fostered professional relationships between the loaned private sector executives and their city counterparts. As deWindt (1981) noted the OITF recommendations were integrated into city operations for two reasons. The first reason is that city employees embraced the OITF study process because they participated in making the decisions about what to change in their own work settings. The second reason is that the loaned executives found that most city employees were dedicated, hard-working, and willing to go beyond the call of duty, despite laboring under inefficient practices, untrained managers, inadequate resources, outdated equipment, and faulty technology. 
Overall, the Cleveland business community became fully invested in Mayor Voinovich's OITF partnership to restore good government in the city. The leadership of the OITF public-private partnership reported that Cleveland:

.. expanded vital channels of communication between the public and private sectors. Without the cooperation of the city's employees, the progress achieved would not have been possible. In addition, task force members have developed a better understanding of the complex problems of municipal government management through their work with agency officials (OITF, 1982).

In fact, many loaned executives stayed involved with their city counterparts on their own time long after the study period ended, and some loaned executives joined the city's workforce. Strategically, the mayor expanded these channels of communication between the public and private sectors to sustain the results of the OITF partnership.

\section{Sustaining Behaviors of Mayor Voinovich (1982- 1989)}

Mayor Voinovich in partnership with Council President Forbes institutionalized the OITF's legacy. In 1981, the council voted to place two OITF-inspired charter amendments on the ballot. One amendment lengthened the terms of the mayor and council members from two to four years in addition to strengthening the mayor's executive powers; the other amendment clarified the prevailing wage requirements for city workers. Both charter changes were approved by the voters. The voters also approved an earnings tax earmarked for debt repayment and capital improvements (Vogelsang-Coombs, 2007).

To sustain the work of the OITF partnership internally, Mayor Voinovich, assisted by philanthropist Morton Mandel, created Project MOVE (Mayor's Operation Volunteer Effort). Overall, Project MOVE channeled 8,000 volunteer business and community leaders into most levels of all city departments (Garda, 2014). To recognize the contributions of the volunteers, Voinovich established the Mayor's Award for Volunteerism and designated "a wall of fame" in Cleveland City Hall, where plaques still hang to honor the MOVE volunteers.

Much has been written about the immediate outcomes of the OITF partnership, so we will only present some highlights. As a result of the OITF, the city secured \$149 million in urban development action grants that leveraged $\$ 770$ million in private investments, including projects for neighborhood revitalization (Mendel \& Brudney, 2012). With the financial assistance of Cleveland Tomorrow, the Voinovich administration facilitated the expansion of Cleveland's neighborhood development organizations (CNDCs) to improve the residents' quality of life, and the number of CNDCs grew from 12 to 35 (Voinovich, 2013). ${ }^{4}$ Because of the OITF partnership, the city was much more active in all of Cleveland's neighborhoods than under previous mayoral administrations.

Additionally, Mayor Voinovich worked with the Greater Cleveland Roundtable, an early supporter of the OITF, to improve race relations, and he integrated the Cleveland police and fire departments under a court order. Given the constraints of limited tax revenue and debt

4 Comprising the CEO's from 44 major Cleveland-based corporations, Cleveland Tomorrow also raised $\$ 855,000$ for economic development projects to attract and retain businesses in Greater Cleveland (Voinovich, 2013). 
financing, the mayor worked with Build-Up Greater Cleveland to raise $\$ 1.6$ billion to renew the city's aging infrastructure (Voinovich, 2013). Finally, the OITF partnership laid the groundwork for the creation of two public-private partnerships that transformed Cleveland's downtown neighborhood. The first partnership developed the North Coast Harbor, where several landmark cultural institutions, including the Rock and Roll Hall of Fame and the Great Lakes Science Center, chose to locate. The second partnership developed Cleveland's signature Playhouse Square. According to Voinovich (2013), more construction happened during his mayoral administration than any other time in Cleveland's history.

Overall, the implementation of Mayor Voinovich's public-private partnership and its sustained effects enabled Cleveland to rise from the ashes of the municipal default into the "comeback city." Cleveland received national recognition by winning the prestigious All-America City Award from the National Civic League three times in the 10 years of the Voinovich administration. On retiring from the Cleveland mayoralty in 1989, Voinovich (2013) had a proud moment because USA Today wrote an article about him and Council President Forbes "as the short white Republican mayor and the tall African-American [Democratic] Council President that worked together to bring about the Cleveland Renaissance."

It is important to note that the OITF leadership identified four critical areas that required ongoing attention by city leaders: personnel management; data processing/information technology management; management organization; and capital investment and maintenance (OITF, 1982). Three issues-personnel management, data processing/technology management, and management organization-resurfaced in 2006 as the priorities of Mayor Frank J ackson's Operations Efficiency Task Force (OETF).

\section{The Five Good Government Partnership Behaviors in the Jackson OETF Partnership}

Table 3 organizes the milestone activities of Mayor J ackson's OETF by the five good government partnership behaviors listed in the top row. The first column divides the OETF into four phases:

(1) the formation of the OETF partnership concept; (2) the development of the OETF; (3) the OETF operations; and, (4) the OETF's follow-up activities.

\section{Activating Behaviors of Mayor J ackson (2006)}

Pundits described Frank Jackson's character as "honest" and "contemplative," a self-effacing politician without "ego or ambition" (Roberts, 2012). His council colleagues perceived him as a man of high integrity, an exceptionally good listener, and an excellent reader of people. J ackson described himself as a "servant-leader" with a social equity mission to make a difference in the lives of citizens, especially "for those among us who have the least." In his view, government was different from the private sector. Although government, he said, benefitted by applying business-oriented efficiency practices in its operations, its bottom line was quality service to people.

Council President Frank J ackson made history in November 2005 for becoming the first sitting council member elected Cleveland mayor since 1867 (Roberts, 2012). After 13 years on the city council, including four years as council president and finance committee chair, Jackson developed extensive technical knowledge of Cleveland's operations. His cooperative relations with Mayor J ane Campbell deteriorated in 2004 when she failed to keep the council informed 
Table 3. OETF Implementation Phases by Good Government Partnership Behaviors of Mayor J ackson

\begin{tabular}{|c|c|c|c|c|c|}
\hline & $\begin{array}{l}\text { Activating } \\
2006\end{array}$ & $\begin{array}{c}\text { Mobilizing } \\
2006\end{array}$ & $\begin{array}{l}\text { Framing } \\
2006-07\end{array}$ & $\begin{array}{c}\text { Synthesizing } \\
2007-08\end{array}$ & $\begin{array}{c}\text { Sustaining } \\
2009-14\end{array}$ \\
\hline $\begin{array}{l}\text { OETF } \\
\text { Partnership } \\
\text { Concept } \\
\text { Formation }\end{array}$ & $\begin{array}{l}\text {-FJ became mayor } \\
\text {-Operations } \\
\text { efficiency as good } \\
\text { government model } \\
\text {-FJ Social equity } \\
\text { mission } \\
\text {-Budget deficit }\end{array}$ & $\begin{array}{l}\text {-Executive Sponsor- } \\
\text { FJ } \\
\text {-PPP Champion - } \\
\text { COO Brown } \\
\text {-Suburban mayors }\end{array}$ & $\begin{array}{l}\text {-OETF Charter } \\
\text {-Mayor's annual } \\
\text { budget meeting with } \\
\text { employees } \\
\text {-Fiscal discipline } \\
\text { required of dept. } \\
\text { heads }\end{array}$ & $\begin{array}{l}\text {-Transparent govt. } \\
\text {-Plain Dealer } \\
\text { briefing } \\
\text {-Mayor's Annual } \\
\text { Report to Citizens }\end{array}$ & $\begin{array}{l}\text {-Cooperation with } \\
\text { the business } \\
\text { community } \\
\text {-Cleveland K-12 } \\
\text { Plan }\end{array}$ \\
\hline $\begin{array}{l}\text { OETF } \\
\text { Partnership } \\
\text { Development }\end{array}$ & $\begin{array}{l}\text {-OEC Council } \\
\text {-Project } \\
\text { Management Office } \\
\text { (PMO) } \\
\text {-Communication } \\
\text { Team } \\
\text {-City Council as ally } \\
\text {-Union cooperation }\end{array}$ & $\begin{array}{l}\text {-Diverse Volunteer } \\
\text { Recruitment: } \\
\text {-Process Leader: } \\
\text { PMO Manager } \\
\text { Whitlow } \\
\text {-Councilman } \\
\text { Westbrook on OEC } \\
\text { Council }\end{array}$ & $\begin{array}{l}\text {-PMO Methodology } \\
\text {-Technical Training, } \\
\text {-Customer Service } \\
\text { Training } \\
\text {-Performance } \\
\text { Measurement } \\
\text { Training }\end{array}$ & $\begin{array}{l}\text {-COO Management } \\
\text { by walking around } \\
\text {-City of Choice } \\
\text { hotline and email } \\
\text { for employee input } \\
\text {-OETF Performance } \\
\text { Dashboards for } \\
\text { Action Teams }\end{array}$ & $\begin{array}{l}\text {-CitiStat Initiated } \\
\text {-CitiStat and } 311 \\
\text { systems merged } \\
\text {-Citywide } \\
\text { performance } \\
\text { dashboards }\end{array}$ \\
\hline $\begin{array}{l}\text { OETF } \\
\text { Operations }\end{array}$ & $\begin{array}{l}\text {-Public sector driven } \\
\text {-Bottom-up, } \\
\text { employee- centered } \\
\text { structure } \\
\text {-No outside funding }\end{array}$ & $\begin{array}{l}-406 \text { OETF } \\
\text { Participants } \\
\text {-24 Action Teams, } \\
\text { co-chaired by } \\
\text { internal lead and } \\
\text { external lead } \\
\text { (volunteer) }\end{array}$ & $\begin{array}{l}\text {-Phase } 1 \text { - } 8 \text { teams } \\
\text {-Phase } 2 \text { - } 16 \text { teams } \\
\text {-Work Process } \\
\text { Mapping \& Process } \\
\text { Improvements } \\
\text {-Performance } \\
\text { Targets identified } \\
\text {-394 } \\
\text { Recommendations }\end{array}$ & $\begin{array}{l}\text {-94\% implemented } \\
\text {-Saved \$71 million } \\
\text {-Balanced budget } \\
\text {-Strategic IT Council } \\
\text {-QOL for citizens } \\
\text {-311 System } \\
\text {-Social equity } \\
\text { initiatives }\end{array}$ & $\begin{array}{l}\text {-Data-driven } \\
\text { performance } \\
\text { appraisals } \\
\text {-Cleveland } \\
\text { Management } \\
\text { Academy } \\
\text {-Career paths }\end{array}$ \\
\hline $\begin{array}{l}\text { OETF } \\
\text { Partnership } \\
\text { Follow-up }\end{array}$ & $\begin{array}{l}\text {-Sub-cabinet cluster: } \\
\text { revitalized } \\
\text { neighborhoods \& } \\
\text { created thriving } \\
\text { downtown } \\
\text { residential district }\end{array}$ & $\begin{array}{l}\text {-Regional economic } \\
\text { development } \\
\text { strategy } \\
\text {-Participation in } \\
\text { NOCCA }\end{array}$ & $\begin{array}{l}\text {-City employees as } \\
\text { internal champions } \\
\text {-Shift to a } \\
\text { Performance } \\
\text { Culture of Customer } \\
\text { Service }\end{array}$ & $\begin{array}{l}\text {-Citywide } \\
\text { perspective } \\
\text {-Inter-local } \\
\text { agreements } \\
\text {-Regional } \\
\text { cooperation }\end{array}$ & $\begin{array}{l}\text {-Emerging Leaders } \\
\text { Cadre } \\
\text {-Brain Gain } \\
\text {-2014 Gay Games } \\
\text {-Won } 2016 \\
\text { Republican Pres. } \\
\text { Nominating } \\
\text { Convention }\end{array}$ \\
\hline
\end{tabular}


about the city's operating deficit and her plans for layoffs and an income tax levy. Jackson felt compelled to run for mayor because, as the chair of the finance committee, he clearly understood Cleveland's fiscal problems and knew what had to be done.

When Mayor J ackson assumed his new office, Cleveland's population was 406,427 (or 167,400 less than 24 years earlier under Mayor Voinovich), and the U.S. Census Bureau identified Cleveland as the nation's poorest (Vogelsang-Coombs \& Denihan, 2008). Despite losing approximately one-third of its 1980 population, Cleveland's service delivery infrastructure had changed little since the Voinovich administration. Moreover, few Fortune 500 companies remained headquartered in the city, Cleveland's steel mills were closed, and local manufacturing companies were struggling. Given that city employees lacked up-to-date hardware, software, and basic computer training, the city's operations were inefficient because few administrative processes were automated. Labor relations were tense because of the layoffs done under the Campbell administration, and the staff downsizing disrupted service delivery to residents.

As the newly elected mayor, Jackson inherited a deficit of $\$ 30$ million from his predecessor. Nevertheless, J ackson refused to sell city assets or use one-time revenues sources to balance the city's budget. For him, good government meant that Cleveland operated efficiently within its tax and revenue base. Thus, the overarching purpose of Mayor J ackson's public-private partnership was to eliminate the city's recurring budget shortfalls and restore its financial stability while rightsizing Cleveland's government and maintaining quality essential city services. Furthermore, the OETF partnership served as the platform from which Mayor J ackson launched his vision of securing a positive future for Clevelanders in addition to making Cleveland a great city again.

Before launching his public-private partnership, Mayor J ackson consulted with Tom Wagner, the law director who supervised Mayor Voinovich's OITF partnership. In the end, J ackson chose not to adopt a cookie-cutter approach to activate his OETF partnership because Cleveland's environment had changed substantially from the time of Mayor Voinovich. Moreover, he was firm that his OETF partnership's approach to operations efficiency would be driven by government and public sector values. Thus, he created the OETF partnership as a broad-based coalition, drawing members from government, business, academia, nonprofit organizations, state and local officials, and former cabinet officials (OETF, 2006). In effect, the mayor structured the OETF partnership to fit Cleveland as he found the city in 2006 and his own leadership style.

Within a month of taking office, J ackson activated the Operations Efficiency Task Force (OETF). At the top of the OETF partnership was the operations efficiency council (see table 4). This council set the partnership's strategic direction in addition to serving as the oversight body. The council's chair was the city's chief operating officer (COO) Darnell Brown. Besides him, seven volunteers, the city's chief technology officer, and three mayoral assistants served on the operations efficiency council. The seven volunteers were prominent community and business leaders, information technology experts, and leadership experts from Cleveland State University.

It is important to note that an active member of the operations efficiency council was Jay Westbrook, a highly respected councilman and a former council president. The Westbrook appointment insured that the city council had significant input into the OETF partnership process and up-to-date knowledge of Cleveland's financial condition. This financial transparency led to the city council's willingness to support the changes emerging from the J ackson OETF partnership with legislation. 
Table 4. The J ackson OETF Partnership Structure

\begin{tabular}{|c|c|c|}
\hline Executive Sponsor & Job Title & Organization \\
\hline Frank G. J ackson & Mayor & City of Cleveland \\
\hline Operations Efficiency Council & Job Title & Organization \\
\hline Darnell Brown, Chair & Chief Operating Officer & City of Cleveland \\
\hline William M. Denihan & Chief Executive Officer & $\begin{array}{l}\text { Cuyahoga County } \\
\text { Community } \\
\text { Mental Health Board }\end{array}$ \\
\hline Lee Friedman & $\begin{array}{l}\text { President \& Chief Executive } \\
\text { Officer }\end{array}$ & Cleveland Leadership \\
\hline Fred Nance & Managing Partner & $\begin{array}{l}\text { Squires, Sanders, and } \\
\text { Dempsey LLP }\end{array}$ \\
\hline Charles Phelps & $\begin{array}{l}\text { Director of Leadership } \\
\text { Procrams }\end{array}$ & $\begin{array}{l}\text { Levin College of Urban } \\
\text { Affairs. CSU }\end{array}$ \\
\hline Dr. Vera Vogelsang-Coombs & MPA Program Director & $\begin{array}{l}\text { Levin College of Urban } \\
\text { Affairs, CSU }\end{array}$ \\
\hline J ay Westbrook & Councilman, Ward 18 & Cleveland City Council \\
\hline Ron Woodford, PMP & Senior Program Manager & VW Group \\
\hline Natoya J. Walker & $\begin{array}{l}\text { Special Assistant to Mayor, } \\
\text { Public Affairs }\end{array}$ & City of Cleveland \\
\hline Barry Withers & $\begin{array}{l}\text { Special Assistant to Mayor, } \\
\text { Employee Services }\end{array}$ & City of Cleveland \\
\hline Michele C. Whitlow & OETF PMO Program Manage & rCity of Cleveland \\
\hline $\begin{array}{l}\text { Dr. Melodie Mayberry-Stewart } \\
\text { (2006 ) }\end{array}$ & Chief Technology Officer & City of Cleveland \\
\hline Communications Advisory Team & Job Title & Organization \\
\hline Natoya J. Walker, Chair & $\begin{array}{l}\text { Special Assistant to Mayor, } \\
\text { Public Affairs }\end{array}$ & City of Cleveland \\
\hline $\begin{array}{l}\text { Montrie Rucker Adams (2006- } \\
\text { 2007) }\end{array}$ & President & Visibility Marketing, Inc. \\
\hline Carol Caruso (2006) & $\begin{array}{l}\text { Senior Vice President, } \\
\text { Advocacy }\end{array}$ & $\begin{array}{l}\text { Greater Cleveland } \\
\text { Partnership }\end{array}$ \\
\hline Marie Galindo (2006) & Owner & Luchita's Restaurant \\
\hline Wayne Hill, APR (2006) & President & Edward Howard and Co. \\
\hline Mary Ann Sharkey (2006-2007) & Chief Executive Officer & Mita Marketing LLC \\
\hline Tom Andrzejewski (2007) & President & Oppidan Group \\
\hline Scott Osiecki (2007) & Director, External Affairs & $\begin{array}{l}\text { Cuyahoga County } \\
\text { Community } \\
\text { Mental Health Board }\end{array}$ \\
\hline Sheila Samuels (2007) & Former Development Director & $\begin{array}{l}\text { Levin College of Urban } \\
\text { Affairs, CSU }\end{array}$ \\
\hline Erica Chrysler (2006) & Deputy Press Secretary & City of Cleveland \\
\hline Jason Wood & $\begin{array}{l}\text { Special Assistant to Mayor, } \\
\text { Boards \& Commissions }\end{array}$ & City of Cleveland \\
\hline Michael House (2006-2007) & General Manager, Channel 23 & City of Cleveland \\
\hline Francis Margaux (2007) & Special Assistant to the Mayor & \\
\hline Maureen Harper (2007) & Chief of Communications & City of Cleveland \\
\hline Ossie Neal (2007) & $\begin{array}{l}\text { Marketing Manager, Division } \\
\text { of Water Pollution Control }\end{array}$ & City of Cleveland \\
\hline OETF Project Management Office & City of Cleveland Employees & $\begin{array}{l}\text { City of Cleveland } \\
\text { Employees }\end{array}$ \\
\hline
\end{tabular}


The Transformative Effect of Public-Private Partnerships

\begin{tabular}{|c|c|c|}
\hline $\begin{array}{l}\text { Michele C. Whitlow, PMO } \\
\text { Manager }\end{array}$ & Gwen Bryant (2006-2007) & $\begin{array}{l}\text { Hollis Crump (2006- } \\
\text { 2007) }\end{array}$ \\
\hline Eduardo Romero (2006) & Shahid Sarawar (2006) & $\begin{array}{l}\text { Cynthia Sullivan (2006- } \\
\text { 2007) }\end{array}$ \\
\hline Elaine Woods (2006-2007) & Valencia Wright (2006-2007) & $\begin{array}{l}\text { Phyllis Fuller Clipps } \\
\text { (2007) }\end{array}$ \\
\hline Bertha Glover (2007) & Ossie Neal (2007) & Celeste Ribbins (2007) \\
\hline Vinita Bose (2007) & Tyeshia Minniefield (Intern) & J eremy Taylor (Intern) \\
\hline
\end{tabular}

Similarly, the city's labor unions became the strategic allies of Mayor J ackson. In March 2006, the mayor briefed the union leadership about his employee-centered operation efficiency plans in light of the city's bleak fiscal condition and unfavorable financial forecasts. Boldly, Jackson asked the labor leaders for temporary contract concessions so that he could balance the city's budget without disrupting service to the residents. Furthermore, the mayor pledged that if the unions made concessions to help him achieve a budget in structural balance, then he would maintain the city's employment levels and not lay off staff. All but one union leader agreed, and the roll backs in the labor contracts immediately saved the city $\$ 30$ million. Mayor Jackson succeeded in gaining labor's cooperation for his OETF partnership because the union leaders trusted him and believed in his integrity.

As shown in table 4, the OETF partnership had a communications advisory team whose membership included public relations professionals from business, government, and the media as well as mayoral assistants and the city's press secretary. This team was responsible for keeping stakeholders and the public informed about the work of the J ackson OETF partnership.

\section{Mobilizing Activities of Mayor J ackson (2006)}

Although Mayor Jackson was the executive sponsor of the OETF partnership; the overall partnership champion was COO Brown. Under Brown's leadership, the operations efficiency council recruited approximately 406 volunteers from the Greater Cleveland Partnership (the regional business chamber) and its affiliate, the Cleveland Leadership Center, as well as alumni of Cleveland State University's MPA Program and Local Officials Leadership Academy (see figure 1). These volunteers contributed more than 12,000 hours of service worth approximately $\$ 1.7$ million in expertise (Vogelsang-Coombs \& Denihan, 2008). Whereas the leadership of Mayor Voinovich's OITF partnership raised approximately \$1 million from the private and nonprofit sectors, Mayor Jackson's OETF public-private partnership existed entirely on the donated time and in-kind services of the volunteers.

The internal process leader of the Jackson OETF partnership was Michele Whitlow, an employee with the Cleveland Water division; she had a mobility assignment to head the OETF project management office (PMO). The PMO staff developed the operations efficiency methodology; standardized formats for the action teams to gather, analyze, and share critical information developed the templates for tracking performance measures; and provided technical assistance during the implementation of the recommendations of the OETF action teams. The PMO staff also had the daily oversight of the action teams and reported monthly to the operations efficiency council.

Finally, the leadership of the Jackson OETF partnership reached out to inner-ring suburban mayors. Three mayors, all of whom had chaired the Cuyahoga Mayors and Managers 
Figure 1. Participants in J ackson OETF Partnership by Sector

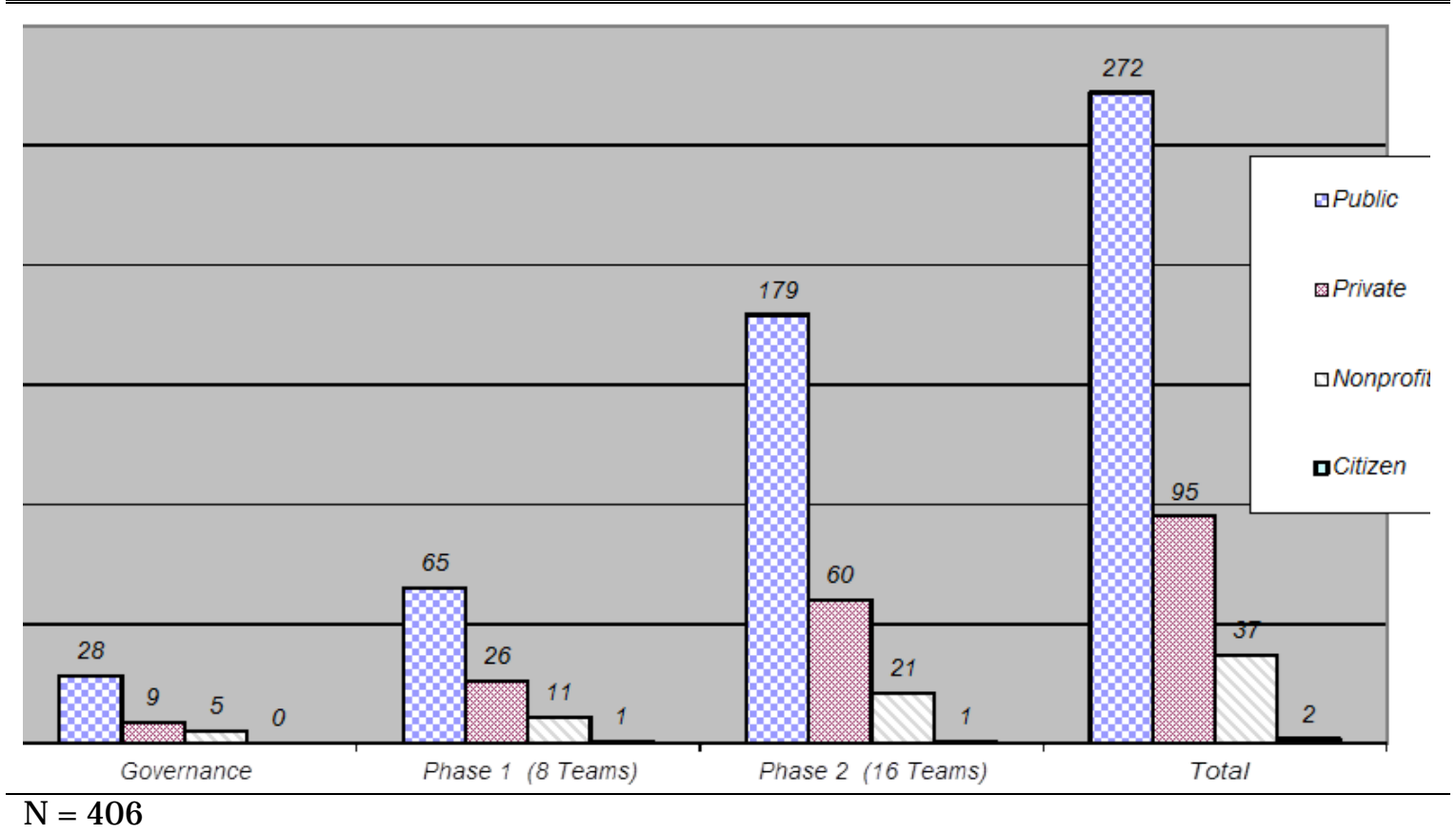

Association, participated in a focus group. ${ }^{5}$ The suburban mayors offered suggestions to increase operational efficiencies with a special emphasis on inter-local service agreements. During the Jackson administration, Cleveland joined the Northeast Ohio City Council Association (NOCCA). Additionally, Mayor J ackson supported a "no poaching" economic development strategy, whereby municipal officials agreed not to lure businesses to relocate from one Greater Cleveland location to another (Vogelsang-Coombs \& Denihan, 2008).

\section{Framing Activities of Mayor J ackson (2006- 2007)}

In April 2006, Mayor J ackson held his first meeting with all OETF volunteers and participating city employees, where he unveiled the charter of his public-private partnership. This charter established the OETF partnership's urgent good (efficient) government purpose. Additionally, the charter expressed the OETF partnership's guiding principles that included Mayor J ackson's commitments to value the expertise of employees, give them with opportunities for retraining, and enable them to share their learning. Besides clarifying the roles and responsibilities of OETF participants, the charter cited 13 critical success factors, including the elimination of service gaps across city departments, the use of innovative solutions in service delivery, and the utilization of technology to enhance data collection and guide decision-making. Thus, the public-private partnership charter framed the mayor's plans to foster a citywide culture of excellent performance and customer service.

To reinforce his commitment to good government principles, Mayor J ackson held meetings with all city employees and stakeholders, including the unions. At these meetings, he reiterated the OETF's partnership purpose of operations efficiency, shared information about the city's financial condition and revenue projections, and pledged to maintain employment under a

5 The participating suburban mayors were Republican Bruce Akers of Pepper Pike, Republican Deborah Sutherland of Bay Village, and Democrat Martin Zanotti of Parma Heights. 
structurally balanced budget. The mayor continued these meetings annually to renew the employees' confidence in the usefulness of the partnership's approach to operations efficiency and to maintain morale.

Also, as a part of the framing process, Mayor J ackson informed his cabinet directors that he expected them to live within their budgets. Accordingly, he ended the practice of padding one department's budget to pay for cost overruns generated in another department. He also informed his directors that the cost savings generated by their departments and divisions would be redistributed to those city operations where they would produce the greatest efficiencies, customer service improvements, and productivity gains.

Specifically, the work of the OETF partnership was divided into two phases: eight action teams operated in Phase 1 (2006-2007), and 16 action teams in Phase 2 (2007-2008). Taken as a group, the OETF action teams covered all aspects of city operations except public safety. ${ }^{6}$ To build the capacity of the action team members, the staff from the OETF project management office (PMO) organized technical, leadership, customer service, and performance measurement training programs for the partnership volunteers and the city employees to participate together at the beginning of their OETF assignments. Given their common training experience, city employees felt comfortable in opening their units up to the outsiders on their action teams. These training sessions also built camaraderie among the city employees who worked in different departments and fostered good will between the city employees and the outside experts.

Each action team was co-chaired by a department director and a volunteer expert (called the external lead). The action teams were given the following four objectives: (1) to reduce operating costs by at least 3\%; (2) to enhance city services by using performance indicators and targets; (3) to increase employee productivity through better use of technology; and (4) improve customer service to internal and external customers (OETF, 2006, 2007). The action teams applied the PMO's performance methodology by assessing the current or "as is" work process for their assigned department or citywide service. After mapping these work processes, the action teams proposed recommendations that contained performance targets and customer service standards designed to achieve the four OETF objectives. Overall, the action teams produced 394 recommendations for improving more than 100 city processes operations from the inside out (OETF, 2007).

Based on their success in producing workable improvement recommendations, city employees developed an identity as the internal champions of operations efficiency. Because these employee-participants were scattered throughout Cleveland's 60 departments and divisions, their work on the OETF action teams informally facilitated a shift in the city's work culture. This shift to a citywide culture of excellent performance and customer service occurred without an

\footnotetext{
${ }^{6}$ Phase 1 Teams focused on the departments of public health, building and housing, public service, and parks, recreation and properties and the citywide services of IT service delivery, human resources, procurement and purchasing, and customer service. Concurrently, the Department of Public Safety, which comprised $60 \%$ of the city's budget, conducted an internal assessment and identified 50 improvement opportunities for implementation. Also, the Greater Cleveland Partnership funded loaned executives to assess the city's fleet of motor vehicles. Phase 2 Teams focused on the departments of aging, city planning, the civil service commission, community development, consumer affairs, economic development, port control and public utilities, Cleveland Public Power (formerly Muny Light), water, and water pollution control. Four additional teams focused on the general support functions provided by the departments of finance and law as well as the Mayor's Offices of Communications and Equal Opportunity (OETF, 2007).
} 
J ournal of Public and Nonprofit Affairs

incident because it was driven by the bottom-up, employee-centered approach of the J ackson OETF partnership.

\section{Synthesizing Behaviors of Mayor J ackson (2007- 2008)}

Mayor J ackson delegated the day-to-day supervision of the OETF action teams to COO Brown. However, if department heads were not meeting their OETF expectations, then the mayor would forcefully "get into their business," demanding to know when and how they would change their lackluster performance. In fact, the mayor removed one intransigent division head that blocked the implementation of the OETF recommendations at the city. In effect, he made it clear that the implementation of the OETF partnership recommendations was a priority, and he was serious about seeing results.

COO Brown and PMO manager Whitlow combined data-driven decision-making and management by walking around. In particular, the PMO staff developed performance dashboards built on the performance targets identified in the OETF recommendations, collected and tracked performance measurements, and reported the results to the action teams. Additionally, the $\mathrm{COO}$ and the PMO staff met with the action teams, including the community volunteers and line employees, in the city's departments and divisions. This practice gave line employees an opportunity to engage with top city officials about their operational needs and aspirations. Interestingly, this practice was replicated by some department directors who opened opportunities for their employees to contribute ideas for operations efficiency and improved customer service.

Furthermore, a "city of choice" hotline and an email address were set up as other channels of safe communication between line employees and the city's top leadership. This propensity for openness among the highest city officials reinforced the validity of Mayor J ackson's employeecentered approach to operations efficiency. The leadership of the OETF partnership extended this propensity for transparent government to the general public. At the end of Phase 2, the communications team published the 2008 Mayor's Annual Report (MAR) to the Citizens of Cleveland. This report highlighted the city's improved performance stemming from the change recommendations of the J ackson OETF partnership, and the city has continued publishing an annual MAR since then.

When the OETF partnership concluded its operations in 2010, the city implemented $94 \%$ of the OETF recommendations. Collectively, the action teams saved \$71 million between 2006 and 2009. Given the substantial annual savings produced by the OETF partnership process, the mayor balanced the city's budget in every year of his first term (2006-2010), including 2008 and 2009 during the Great Recession, all without disruptive staff layoffs. Additionally, the J ackson OETF partnership improved the quality of life for citizens, including more timely snow removal, street repair, and waste collection, and more frequent sweeping of residential streets. The city also instituted a recycling program. With no new additional resources, Mayor J ackson reopened the city's neighborhood-based recreation centers that were closed under previous mayors due to tight budgets. As a result of the OETF improvements, the recreation centers extended their hours to Saturdays, and the city added a new recreation center.

The J ackson OETF partnership facilitated opportunities for employees to develop a citywide perspective. In Phase 1 of the OETF partnership, the city established the Strategic Information Technology Council. This council had the oversight of the deployment and utilization of IT systems across the departments to insure the city's technology aligned with the OETF 
partnership's strategic goals. As a result, the city adopted web-enabled interactive portals for citizen access, established a system of e-permitting, and provided field personnel with handheld computers that had direct access to their operational systems. In 2008, the city launched a "3-1-1" communication system that allowed residents to report and receive faster service in nonemergency situations.

In addition, the city established two noteworthy cross-departmental initiatives to serve older and younger residents. The senior initiative involved six departments that helped older residents (persons aged 60 and over) upgrade their homes to meet housing codes. The youth initiative, called "One Voice, Zero Tolerance," involved staff from three departments and the mayor's office; together they developed a package of education, prevention, intervention, and workforce training services. Both initiatives were still working in 2014.

Finally, the Jackson OETF partnership process extended the cooperation between the city of Cleveland and suburban jurisdictions. As a result of some OETF recommendations, the city established agreements with contiguous jurisdictions related to overlapping functions, such as snow removal and street repair. Mayor J ackson also worked with the Cuyahoga County Mayors and Managers Association to develop joint economic agreements tied to Cleveland water service, in which participating cities shared taxes from relocating industries (J ackson, 2009).

\section{Sustaining Behaviors of Mayor J ackson (2009- 2014)}

One way Mayor Jackson sustained the OETF improvements internally was by investing in CitiStat, a data-driven work management system developed in Baltimore. In 2011, the city merged the CitiStat and "3-1-1" systems to create a citywide performance dashboard. This enhanced dashboard gave employees up-to-date data on their response time to citizen complaints, while department directors gained information about under-served areas of the city. The general public had access to these performance data because the city published the citywide performance dashboard in the Mayor's Annual Report to the citizenry.

Another way the city sustained the OETF efficiency and productivity gains was by making staff training and development mayoral priorities. Cross-functional training, mobility assignments, and internships were used to develop in-house talent and help establish career paths for city employees. In a partnership with Cleveland State University and the Cleveland Foundation, the city established the Cleveland Management Academy (CMA) in 2009. Specifically, the CMA was a year-long management development program aligned with the objectives of the J ackson OETF partnership (Starzyk, 2009). Mayor Jackson (2009) reported that he promoted eight CMA graduates into positions of department directors and city commissioners (without knowing they were CMA alumni) because they were the best candidates. Thus, the J ackson OETF partnership facilitated the creation of a citywide cadre of emerging leaders who successfully competed for upper-level leadership positions.

Although Cleveland business leaders were nervous about Mayor J ackson in 2006, he captured their support because of his stewardship of the city through the OETF public-private partnership. The mayor impressed the business community because the cost savings and productivity improvements that emerged from his OETF partnership enabled Cleveland to survive the Great Recession better than many other cities in the nation (Trickey, 2013). Mayor J ackson - who was reelected in 2009 and 2013-used the respect he earned from the business 
community to implement his visionary "Cleveland Plan" to transform the city's underperforming and insolvent school district (Garda, 2014). ${ }^{7}$

Finally, Cleveland received national attention for its success in implementing the "new urban renewal" (Hyra, 2012). As a part of the OETF, Mayor J ackson created an economic development cluster in his cabinet to work with the private sector to generate extensive neighborhood revitalization in addition to transforming the city's aging downtown into a thriving residential district. Cleveland also experienced a "brain gain," as young professionals made Cleveland their "city of choice." Trickey (2013) attributed these transformational effects to Mayor Jackson's leadership:

A mayor from Cleveland's poorest neighborhoods is presiding over a downtown population boom, and a surge of vitality is attracting young professionals to the city's near West Side. J ackson helped those changes along with reliable services, a rejuvenated economic development department, strategic spending at key moments, and the more tangible aspects of his sustainability effort, from bike lanes to support of the local food movement.

Additional evidence that Cleveland was a city of choice occurred in 2014. Besides serving as the venue for the international Gay Games, Cleveland was chosen in a highly competitive selection process as the venue for the Republican Party's 2016 presidential nominating convention. The transformation of Cleveland into a city of choice would not have occurred without the results of Mayor J ackson's public-private partnership that were reinforced by his vision of good (efficient) government and his philosophy of servant-leadership.

\section{Lessons Learned \& Governance Implications}

Our analysis of the public-private partnerships of Mayor Voinovich and Mayor J ackson from the inside out produced three lessons. The first lesson is that each mayor tailored the structure and the objectives of his public-private partnership to fit not only to his particular leadership style but to succeed in addressing declining population and revenue needs of Cleveland during their moment in office. Specifically, Mayor Voinovich organized the OITF public-private partnership as a tactical strike force. His partnership used a top-down hierarchical structure and was generously funded by Cleveland's business, nonprofit, and labor communities to deal with the urgency of the municipal default. He achieved the objectives of the OITF partnership for increasing the efficiency and the cost-effectiveness of administrative operations to end the default. Given his strategic alliance with Council President Forbes, Mayor Voinovich achieved long-term managerial, operating, and organizational improvements in municipal governance. Based on the work of the OITF partnership, Mayor Voinovich pinpointed 14 major administrative projects in need of additional study; he used funds raised by the OITF partnership to implement productivity improvements for the long-term management of Cleveland's finances and service delivery.

7 This Cleveland Plan integrated the city's network of charter schools into the Cleveland municipal school district. In this way, Cleveland families living in neighborhoods with underachieving public school had access to high-quality options available for their children's education. Then, in 2012, the mayor mobilized a bipartisan coalition comprising prominent business and community leaders, teachers' unions, teachers, parents, as well as key state and county officials that secured legislation and a tax levy to sustain the innovative Cleveland Plan (O’Donnell \& Guillen, 2012; Trickey, 2013). 
In contrast, Mayor Jackson organized his OETF public-private partnership as a strategic campaign. His partnership used a bottom-up, flat structure driven by public sector values and the donated contributions of the outside volunteers. Mayor J ackson successfully achieved a structurally balanced budget and modernized administrative operations. He also achieved the objectives of the OETF partnership of reducing operating costs by 3\%, applying performance measures to improve city services, using technology to increase employee productivity, and improving service delivery to internal and external customers. Building on the success of the OETF partnership, Mayor J ackson garnered the support of the Cleveland business community, and he achieved major transformational changes in the city, such as the innovative Cleveland Plan for reinventing K- 12 education.

The second lesson highlights how the mayors gained the trust of city employees for their publicprivate partnerships. Both the Voinovich and Jackson partnerships created an employeecentered process to study and improve administrative operations. Specifically, the Voinovich partnership concentrated on gaining the support of the city commissioners (the highest civil service employees), thereby tapping into their expertise, institutional knowledge, and role in supervising staff. The Jackson partnership concentrated on gaining the support of the city's labor unions to ease tensions in employee relations. Both partnerships set ground rules for the volunteers to treat city employees respectfully by listening to their ideas, advising them on best practices from the corporate and nonprofit sectors, and suggesting operational improvements. After the employees and the volunteers merged ideas and improvement recommendations, they co-designed performance measures. This process contributed to employee ownership for the implementation of the partnership's change proposals. It also led to creativity, innovation, and sustained improvements in city operations.

The third lesson focuses on the effects of participation in the Voinovich and J ackson publicprivate partnerships. Feedback from city employees revealed how much they gained from the perspective of the volunteers; the volunteers reported they had a "newfound respect" for the professionalism and competence of city employees. For city employees, in particular, their participation in the mayoral public-private partnerships served a liberating experience. These "liberated" employees became the advocates of professional management at city hall and informally created a city-wide network of internal change agents. This network of internal employee-change agents seamlessly engineered the professionalization of the city's work culture from the bottom up. For the outside volunteers, their participation in the mayoral public-private partnerships had an educative effect. The volunteers were impressed by the dedication and competence of city employees from whom they learned how Cleveland's government really works, and many developed permanent friendships with their city counterparts. Through this educational experience, the volunteers deepened their affiliation with the city of Cleveland.

Three governance implications emerge from these lessons. The first implication is that a publicprivate partnership oriented toward operations efficiency is not just for a newly elected mayor facing a crisis. Both Mayors Voinovich and Jackson advocated using a public-private partnership oriented toward operations efficiency on a regular basis. Mayor Voinovich felt that Cleveland would benefit by renewing a public-private partnership oriented toward operations efficiency every six years because "people get stale and their good habits disappear." Similarly, Mayor J ackson (2009) felt that the implementation of another OETF partnership would keep people from "going back to their old ways" because "someone was watching." Apart from the Hawthorne effect, a public-private partnership oriented toward operations efficiency can alert a mayor to data-processing problems and to the availability of new technology and software to drive performance decisions. Thus, a public-private partnership can help a city avoid getting dangerously behind on automation. Also, the cross-departmental relationships fostered in a 
public-private partnership can help a mayor develop a comprehensive approach to service delivery rather than to rely on a complaint-driven system that fragments administrative responses.

The second implication concerns the timing of a mayoral-led public-private partnership. The implementation of a public-private partnership is easier politically for newly elected mayors than for incumbent mayors. Incumbent mayors may be reluctant to implement a needed publicprivate partnership because they may not want to give the voters the impression that their administrations are unstable. The perception of an unstable administration could erode their chances for reelection. Thus, incumbent mayors should tailor their public-private partnership to address a few priority issues, as Mayor Voinovich did in his follow-up to the OITF partnership.

The third implication concerns citizen participation. Neither the Voinovich OITF partnership nor the Jackson OETF partnership incorporated lay citizens. The tendency in a mayoral-led public-private partnership is to recruit outsiders who can bring specific expertise to advise city employees. However, there is value for a mayor to work with council members to include lay citizens in a public-private partnership oriented toward operations improvement because lay citizens are the true barometers of service quality. As partnership members, lay citizens can assess the status of service delivery in their neighborhoods, contribute to the design of a publicprivate partnerships change proposals, and evaluate service delivery improvements, all from the perspective of the end users.

\section{Conclusion}

This research paper analyzed the good government characteristics of the public-private partnerships led by Mayor Voinovich and Mayor J ackson in Cleveland, Ohio. Our research method applied and extended the network theory of McGuire and Agranoff. We evaluated the Voinovich and Jackson partnerships against the backdrop of five network (partnership) behaviors: activating, mobilizing, framing, synthesizing, and sustaining. These behaviors were general categories that not only provided a complete inside picture of both mayoral-led partnerships but enabled the discernment of their short- and long-term (transformational) results. The sustained effects of the Voinovich OITF public-private partnership transformed Cleveland into the "comeback city" after the 1978 municipal default. The sustained effects of the Jackson OETF public-private partnership positioned Cleveland as the "city of choice" in 2014. In effect, both mayoral-led public-private partnerships quietly transformed Cleveland's government to meet the demands of fewer resources, greater complexity, more transparency, and more timely decisions in the delivery of public services to citizens.

Finally, it is important to note that no algorithm existed for designing a mayoral-led public private partnership, even in the single setting of Cleveland. Consequently, the five network (partnership) behaviors can guide a mayor in adapting a public-private partnership to fit his or her leadership style, the environment of urban governance, and the urgent needs of citizens. Furthermore, the findings from our application of network theory may serve as propositions for future researchers to test. Empirical testing will deepen knowledge about the transformational effects of a mayoral-led public-private partnership in municipal governance. 
The Transformative Effect of Public-Private Partnerships

\section{Disclosure Statement}

The authors declare that there are no conflicts of interest that relate to the research, authorship, or publication of this article.

\section{References}

Ansell, C., \&Gash, A. (2008). Collaborative governance in theory and practice. J ournal of Public Administration Theory and Practice, 18, 543-571. doi:10.1093/jopart/mum032

deWindt, E. M. (1981). Speech to the University Club, Seattle, Washington. Cleveland, $\mathrm{OH}$ : Eaton Corporation Archives.

Garda, A. L. (2014.). K-12: The Cleveland plan. Retrieved from http:// www.gcpartnership.com/See-What-We-Do/ Education-Reform

Hyra, D. S. (2012). Conceptualizing the new urban renewal: Comparing the past to the present. Urban Affairs Review, 48, 498-527. doi:10.1177/ 1078087411434905

Jackson, F. G. (2009). Mayor's annual report to the citizens of Cleveland, 2008. Cleveland, OH: Cleveland Mayor's Office.

McGuire, M., \& Agranoff, R. (2011). The limitations of public management networks. Public Administration, 89, 265-284. doi:10.1111/j.1467-9299.2011.01917.x

McGuire, M., \& Agranoff, R. (2014). Network management behaviors: Closing the theoretical gap. In R. Keast, M. P. Mandell, \& R. Agranoff (Eds.), Network theory in the public sector: building new theoretical frameworks (pp. 137-156). New York, NY: Routledge.

Mendel, S. C., \& Brudney, J . L. (2012). Putting the NP in PPP: The role of nonprofit organizations in public-private partnerships. Public Performance and Management Review, 35(4), 617-642.

O’Donnell, P., \& Guillen, J . (2012). Mayor Frank J ackson, Ohio Governor J ohn Kasich announce Cleveland schools reform plan. Cleveland Plain Dealer. Retrieved from

http:// www.cleveland.com/open/index.ssf/2012/05/cleveland schools reform plan.ht $\underline{\mathrm{ml}}$

Operations Efficiency Task Force. (2006). Final report of phase 1 recommendations. Cleveland, $\mathrm{OH}$ : City of Cleveland Mayor's Office.

Operations Efficiency Task Force. (2007). Final report of phase 2 recommendations. Cleveland, $\mathrm{OH}$ : City of Cleveland Mayor's Office.

Operations Improvement Task Force. (1982). Operations improvement task force final report on implementation. Retrieved from http:// www.voinovich.collections.library.ohio.edu/items/ show/ 579

Riffe, F. C. (1999). Words and deeds: The achievements of Governor George Voinovich. Athens, $\mathrm{OH}$ : Ohio University Special Publications.

Roberts, M. D. (2012). Cleveland in the 2000s. Retrieved from http:// www.teachingcleveland.org/images/pdf/cleveland\%20in\%20the\%202000s\%20b y\%20mike\%20roberts.pdf

Starzyk, E. (2009). Yearlong program at Cleveland State University will train Cleveland employees to be more efficient. Cleveland Plain Dealer. Retrieved from http:// www.cleveland.com/business/index.ssf/2009/09/yearlong_program at clevela nd.html

Steiner, C. (1999). Foreward. In F. C. Riffe, Words and deeds: The achievements of Governor George Voinovich (pp. xi-xiv). Athens, OH: Ohio University Special Publications.

Trickey, E. (2013). It is time to stop underestimating Frank J ackson. Cleveland Magazine. Retrieved from 
http:// www.clevelandmagazine.com/ME2/dirmod.asp?sid=E73ABD6180B44874871A91 F6BA5C249C\&nm=\&type=Publishing\&mod=Publications::Article\&mid=1578600D808 04596A222593669321019\&tier=4\&id=20C53FB7794E446889A0392CA8E1DBFF

Vogelsang-Coombs, V. (2007). Mayoral leadership and facilitative governance. American Review of Public Administration, 37, 198-225. doi:10.1177/0275074006289915

Vogelsang-Coombs, V., \& Denihan, W. M. (2008, May 1). Mayor J ackson uses performance measurement to achieve results and advance social equity in Cleveland. PA Times, pp. 45.

Voinovich, G. V. (2013). [Speech to leadership Cleveland]. Copy in possession of the private collection of George V. Voinovich.

\section{Author Biographies}

Vera Vogelsang-Coombs is an associate professor of public administration and a Voinovich Fellow at the Maxine Goodman Levin College of Urban Affairs of Cleveland State University. She served on the Operations Efficiency Council the oversight body of Mayor Jackson's Operations Efficiency Partnership from 2006- 2009.

William M. Denihan is the chief executive officer of the Alcohol, Drug Addiction, and Mental Health Services Board of Cuyahoga County. He also served on the Operations Efficiency Council, the oversight body of Mayor J ackson's Operations Efficiency Partnership from 2006- 2009. Mr. Denihan was involved in Mayor Voinovich's Operation Improvement Task Force because he held leadership positions in Cuyahoga County and in state government, including state personnel director, the director of the State Employment Relations Board (SERB), and other cabinet level positions under Governor Celeste.

Melanie F. Baur is the manager of programming for the Cleveland Council on World Affairs. Previously she served as research project coordinator in the Office of Senator George Voinovich in the Urban Center at the Maxine Goodman Levin College of Urban Affairs of Cleveland State University. 